\title{
Belowground biomass models for young oligotrophic Scots pine stands in Latvia
}

\author{
Laura Kenina, \\ Andis Bardulis, \\ Roberts Matisons, \\ Rolands Kapostins, \\ Aris Jansons
}

\begin{abstract}
The increasing interest in carbon budget estimation and the growing use of woody biomass in bioenergy production raises the necessity for precise estimates of belowground biomass and soil carbon pools in forest ecosystems, particularly in terms of changes in the age structure of forests. The aim of this study was to estimate the belowground biomass of young ( $<40$ years) stands of Scots pine (Pinus sylvestris L.) in Latvia. The biomass of small roots (diameter 2-20 mm), coarse roots (diameter $>20 \mathrm{~mm}$ ), and stumps of 39 trees from eight stands growing on dry, nutrient-poor mineral soils was measured and compared to the aboveground variables of sampled trees. The results revealed that stumps, small roots, and coarse roots comprised $43 \%, 35 \%$ and $22 \%$, respectively, of the belowground biomass of young Scots pines. The proportion of belowground biomass over the total tree biomass was age-dependent, ranging from $33 \%$ to $17 \%$ for 8 -year and 40 -year old trees, respectively. Aboveground tree variables were significantly correlated with the belowground biomass, being stemwood volume and basal area the best predictors $\left(R^{2}=\right.$ $0.86-0.98$, relative errors $=26-43 \%$ ) of the belowground biomass components. Accordingly, the developed models produced more accurate estimates compared to previous models for the region, thus reducing the uncertainty in determining the carbon budget for belowground biomass. Still, an analysis of a more comprehensive dataset is needed to account for the effect of the social status of trees, as well as the within- and between-stand variation.
\end{abstract}

Keywords: Hemiboreal Forests, Europe, Pinus sylvestris, Allometric Equation, Coarse Roots, Total Root Biomass ton et al. 2003), indicating a large variability and uncertainty in belowground $C$ estimations (Finér et al. 2011, Addo-Danso et al. 2016). The root system consists of various components which are difficult to be directly estimated, despite their vital role in the development and functioning of trees (Makkonen \& Helmisaari 1998, Ohashi et al. 2007). Numerous field methods and allometric models for the estimation of aboveground biomass have been previously published (Sanford \& Cuevas 1996, Neumann et al. 2016). Contrastingly, the development of accurate methods for quantifying belowground biomass has lagged behind, primarily due to methodological challenges and the laborious and costly collection of empirical data on heterogeneous root sys-
Latvian State Forest Research Institute Silava, Rigas Street 111, LV-2169 Salaspils (Latvia)

@ Laura Kenina (laura.kenina@silava.lv)

Received: Jul 14, 2017 - Accepted: Dec 20, 2017

Citation: Kenina L, Bardulis A, Matisons R, Kapostins R, Jansons A (2018). Belowground biomass models for young oligotrophic Scots pine stands in Latvia. iForest 11: 206-211. - doi: 10.3832/ifor2553-010 [online 2018-03-01]

Communicated by: Claudia Cocozza tems (Brassard et al. 2011, Varik et al. 2013

Many factors, such as location (climate), species, age, forest type, and soil oxygen and moisture regime, influence the development of root system of trees (Makkonen \& Helmisaari 1998, Dieter \& Elsasser 2002, Finér et al. 2007). Accordingly, the need to develop local, site-based belowground biomass models for various tree species has been recognized throughout Europe (Zianis et al. 2005, Muukkonen \& Mäkipää 2006). Emphasis has been placed on the extension of models across different species, in order to predict belowground biomass using easy-to-measure aboveground variables of trees (Chakraborty et al. 2016,

Scots pine (Pinus sylvestris L.) is one of the main tree species in the Eurasian boreal and boreo-nemoral zone, representing about $20 \%$ of northern forests (Hytteborn et al. 2005). In Europe, it is an economically important species that can withstand various weather extremes (Dieter \& Elsasser 2002). Whilst numerous studies on Scots pine biomass have been conducted in Fennoscandia (Finér et al. 2007, Repola 2009), studies on belowground biomass of Scots pine in the Baltic region are scarce, though some results have been recently published (Bardulis et al. 2012, Liepins et al. 2018). López-Serrano et al. 2015). Neumann et al. 2016). 
Moreover, from 1990 to 2010, the proportion of young Scots pine stands have increased, due to the intensification of harvesting (58- $62 \%$ of total annual increment harvested - Levers et al. 2014) and of natural disturbances related to climate change (Seidl et al. 2014). Therefore, understanding the dynamics of belowground biomass and the $C$ sink capability of Scots pine young trees and stands is crucial (Pajtík et al. 2008).

The aim of this study was to estimate root biomass and to develop models for the assessment of belowground biomass of young Scots pine stands growing in oligotrophic conditions in Latvia.

\section{Material and methods}

\section{Study sites and sampling}

Latvia is situated in the hemiboreal forest zone, with mixed broad leaf-coniferous forests (Ahti et al. 1968). In the study area, the mean annual temperature was $+6.4^{\circ} \mathrm{C}$, ranging from $-5.3^{\circ} \mathrm{C}$ in January to $+17.3^{\circ} \mathrm{C}$ in July, with the mean annual precipitation of $640 \mathrm{~mm}$ (LEGMC 2016). Scots pine covers $29 \%$ of the total forest area in Latvia, and approximately half of the stands are located on dry mineral soils (Baumanis et al. 2014). Turf podsoled soils cover more than half of the country (IUCN 1993).

The study material was collected from eight stands during the vegetation period (June to August 2015). The age of the sampled trees ranged from eight to 40 years. Seven of the studied stands had been regenerated using 2-year-old, bare-rooted or containerized seedlings; the soil had been prepared by disk trenching. One of the youngest stands was left to regenerate naturally, without soil preparation. The stands were located on dry, nutrient-poor sandy and silty automorphic soils, and corresponded to Cladinoso-callunosa, Vacciniosa and Myrtillosa forest types, according to the classification by Bušs (1976), which represent the typical conditions of Scots pine forests in Latvia.

In each stand, one circular sampling plot was established (eight sampling plots in total). The plot size varied according to the stand's age: $100 \mathrm{~m}^{2}$ (diameter $=11.28 \mathrm{~m}$ ) in stands younger than 15 years, and $500 \mathrm{~m}^{2}$ (diameter $=25.24 \mathrm{~m}$ ) in the others. In each plot, the diameter at breast height ( $\mathrm{DBH}, \pm$
$0.1 \mathrm{~cm})$ of all trees and the height $(\mathrm{H}, \pm 0.1$ $\mathrm{m}$ ) of 10 sample trees were measured (Tab. 1). To determine the forest type, soil samples were collected from all sampling plots (Tab. 1).

In total, 39 sample trees (2-6 trees per plot), according to the distribution of $\mathrm{DBH}$ classes in the stands, were selected randomly for destructive sampling of their root biomass. Trees with visible signs of disease, stem defects (e.g., broken top, double stems), or leaders were avoided. To assess total tree biomass, the fresh weight of aboveground components was determined $( \pm 0.02 \mathrm{~kg})$. Stumps with root components were carefully dug out by hand, separated from soil particles, and washed. The fresh weight of small roots (diameter 2-20 mm), coarse roots (diameter > 20 $\mathrm{mm}$ ), and the stump (Finér et al. 2011) was measured $( \pm 0.02 \mathrm{~kg})$. Fine roots (diameter $<2 \mathrm{~mm}$ ) were not collected, as they are associated with the soil microflora, and thus their accurate weight is difficult to assess (Aalde et al. 2006). The stump components included both belowground and aboveground (5-8 cm above the root collar) parts. For the smallest trees $(\mathrm{DBH}<5.6$ $\mathrm{cm}$ ), representing all of the 8-year-old sample trees and the six smallest of the 12- to 14-year-old sample trees, only small roots were found. Samples of fresh weight from the tree components (with bark) were collected, dried at $105{ }^{\circ} \mathrm{C}$, and weighed separately for calculating the dry biomass, in accordance with Uri et al. (2002).

\section{Data analysis}

Pearson's correlation analysis was used to determine the relationships between the measured variables. To ensure a wide application to the established models of belowground biomass, they were not developed for specific forest site types. Models for stumps, small, and coarse roots, as well as total belowground biomass, were developed for individual trees, based on the aboveground variables: $\mathrm{DBH}, \mathrm{H}$, and approximations of stem basal area ( $\mathrm{S}=$ $\left.\mathrm{DBH}^{2}\right)$ and stemwood volume $\left(\mathrm{V}=\mathrm{DBH}^{2} \cdot \mathrm{H}\right)$. The regression model (eqn. 1) was:

$$
y_{i}=a+b\left(x_{i}\right)
$$

where $y_{\mathrm{i}}$ is the belowground biomass component $(\mathrm{kg})$ of the $i$-th tree, $x_{i}$ represents the independent variables (predictor) for the tree, and $a$ and $b$ are the parameters to be estimated. Additionally, models based on $\mathrm{DBH}$ and $\mathrm{H}$ as predictors were evaluated (eqn. 2):

$$
y_{i}=a+b(D B H)+c(H)
$$

where $a, b$ and $c$ are the parameters to be estimated.

To select the best fitting model for the estimation of belowground biomass components, $R^{2}$ value, F-value, relative error (RE), root-mean square deviation (RMSE), and the Akaike's information criterion (AIC) were used. Modelled data residuals were graphically checked for normality, linearity, homoscedasticity, independency and outlier identification. A logarithmic transformation of data was tested, but preliminary results showed a worst fit to the empirical data; hence, simple linear models were applied. Differences between model predictions and the observed biomass were assessed using t-tests $(\alpha=0.05)$.

To assess the accuracy of the developed models, their predictions were compared to predictions from the models of Repola (2009) for Scots pine stumps and roots (diameter $>10 \mathrm{~mm}$ ), which have been previously applied in the Baltic Sea region. Coarse root and small root biomass were summed to obtain total root biomass for comparison. The accuracy of the model recently developed for Scots pine belowground biomass in Latvia (Liepins et al. 2018) was also tested, with an emphasis on young stands. The comparisons were made by $t$-test for paired observations. All statistical analyses were made using the software $R$ version 3.3.1 ( $R$ Core Team 2016).

\section{Results}

The DBH and $\mathrm{H}$ of the sampled trees $(n=$ 39) ranged from 1.2 to $18.6 \mathrm{~cm}$, and from 2.2 to $17.5 \mathrm{~m}$, respectively. The mean total belowground biomass $( \pm 95 \%$ confidence interval, $\mathrm{Cl}$ ) of young Scots pine was $11.32 \pm$ $5.34 \mathrm{~kg}$, comprising $12-58 \%$ of the total tree biomass. The mean ratio ( \pm standard deviation) of the belowground and total tree biomass decreased with tree age; for 8-, 14-, 24- and 40-year-old Scots pine, it was $0.33 \pm 0.07,0.21 \pm 0.06,0.16 \pm 0.03$ and 0.17 \pm 0.01 , respectively. Since not all of the trees had coarse roots, the stump ap-

Tab. 1 - Characteristics of sampled Scots pine stands. (H): tree height; (DBH): mean diameter at breast height of sampled trees.

\begin{tabular}{ccccccccc}
\hline $\begin{array}{l}\text { Stand } \\
\text { age }\end{array}$ & \multicolumn{2}{c}{ Stand location } & $\begin{array}{c}\text { No. of } \\
\text { sampled } \\
\text { trees }\end{array}$ & $\begin{array}{c}\mathbf{H} \\
\mathbf{( m )}\end{array}$ & $\begin{array}{c}\text { DBH } \\
\mathbf{( c m})\end{array}$ & $\begin{array}{c}\text { Basal area } \\
\left(\mathbf{m}^{2} \mathbf{h a}^{-1}\right)\end{array}$ & $\begin{array}{c}\text { Stand density } \\
\left.\text { (tree ha }^{-1}\right)\end{array}$ & Forest type \\
\hline 8 & $56^{\circ} 50.54^{\prime}$ & $24^{\circ} 38.33^{\prime}$ & 12 & 2.6 & 2.0 & 2.1 & 6200 & Myrtillosa \\
& $56^{\circ} 50.60^{\prime}$ & $24^{\circ} 38.34^{\prime}$ & & & & & & \\
12 & $56^{\circ} 34.58^{\prime}$ & $25^{\circ} 01.21^{\prime}$ & 2 & 4.0 & 6.6 & 7.3 & 2145 & Cladinoso-callunosa \\
\hline 13 & $56^{\circ} 24.58^{\prime}$ & $25^{\circ} 11.21^{\prime}$ & 5 & 4.6 & 5.2 & 4.8 & 2215 & Cladinoso-callunosa \\
\hline 14 & $56^{\circ} 51.34^{\prime}$ & $24^{\circ} 35.01^{\prime}$ & 6 & 4.8 & 5.3 & 7.2 & 3200 & Myrtillosa \\
\hline 24 & $56^{\circ} 41.00^{\prime}$ & $24^{\circ} 27.43^{\prime}$ & 10 & 10.0 & 11.0 & 13.2 & 1385 & Vacciniosa \\
\hline 40 & $56^{\circ} 43.00^{\prime}$ & $24^{\circ} 34.62^{\prime}$ & 4 & 17.5 & 19.5 & 17.1 & 575 & Cladinoso-callunosa \\
\hline
\end{tabular}


peared to be the largest belowground component, followed by small roots, then coarse roots (Tab. 2 ). The estimated total belowground biomass of individual trees was highly variable, ranging from 0.7 to $67.4 \mathrm{~kg}$. The mean biomass $\pm \mathrm{Cl}$ of the coarse roots, small roots, and stumps was $7.99 \pm 4.29,2.08 \pm 0.65$ and $4.18 \pm 1.91 \mathrm{~kg}$, respectively.

Significant correlations $(0.61<r<0.99)$ between the root biomass components and the tree variables were observed (Tab. 3). The belowground biomass components had a stronger correlation with $\mathrm{DBH}$ than with $\mathrm{H}$, as the mean $\mathrm{r}$ was 0.91 and 0.76 , respectively (Tab. 3). Trees with a larger DBH $\left(R^{2}=0.78\right)$ and $H\left(R^{2}=0.68\right)$ had greater total belowground biomass, indicating an age-dependent increase (Tab. 3); however, the age effect was not included in the calculations, as it correlated with both DBH and $\mathrm{H}(\mathrm{r}=0.69$ and 0.93 , respectively; Tab. 3). Total belowground biomass was highly correlated $(r=0.99)$ with coarse root and stump biomass.

The allometric belowground biomass models (eqn. 1) based on stemwood volume $(\mathrm{V})$ and stem basal area (S) gave the most precise estimates $\left(R^{2}=0.80-0.98\right)$ of root biomass components (Tab. 4), particularly for total belowground $\left(R^{2}=0.98\right)$ and coarse root $\left(R^{2}=0.98\right)$ biomass. The models including $\mathrm{V}$ as predictor of total, coarse root, and stump biomass estimation demonstrated the highest precision $\left(\mathrm{R}^{2}>\right.$ 0.92 ), but the best model for small root biomass prediction $\left(R^{2}=0.86\right)$ included $S$ as predictor (Tab. 4). Averaged across the sites, the modelled values gave a RE of only $3.6 \%$ in the weighed total belowground biomass. Both parameters of the biomass models were significant $(p<0.05)$, except for the intercept for the coarse roots model (Tab. 4). Graphical analysis showed that models based on $\mathrm{S}$ and $\mathrm{V}$ best performed in the estimation of root biomass components; however, the REs for the total belowground and coarse root biomass were $26 \%$ and $43 \%$, respectively, indicating different predictive performances (Tab. 4). The variance explained by the models based on both $\mathrm{H}$ and $\mathrm{DBH}$ as independent variables was lower $\left(R^{2}=0.54^{-}\right.$ 0.82).

The models proposed by Repola (2009) and Liepins et al. (2018) significantly ( $\mathrm{p}<$ 0.001 ) underestimated the actual belowground biomass of young Scots pine in oligotrophic stands, and their predictions were lower compared to our models (Fig. 1). Accordingly, the RE for the predictions of total belowground biomass was $76 \%$ using the model proposed by Repola (2009) and $68 \%$ using the model proposed by Liepins et al. (2018). Our model of total belowground biomass for young Scots pine in Latvia gave a substantially higher proportion of variance explained ( $R E=26 \%$ ), thus reducing the RE by $42 \%$ compared to both previously published models.
Tab. 2 - Mean ratios of root components biomass ( \pm standard deviation) from the measured tree biomass. (AGB): Aboveground biomass; (BGB): belowground biomass.

\begin{tabular}{lcccc}
\hline $\begin{array}{l}\text { Root ratio from } \\
\text { tree biomass components }\end{array}$ & $\begin{array}{c}\text { Small roots } \\
(2-20 \mathrm{~mm})\end{array}$ & $\begin{array}{c}\text { Coarse roots } \\
(>20 \mathrm{~mm})\end{array}$ & Stump & Total BGB \\
\hline Ratio of total BGB & $0.35 \pm 0.17$ & $0.22 \pm 0.21$ & $0.43 \pm 0.12$ & - \\
Ratio of AGB & $0.12 \pm 0.10$ & $0.05 \pm 0.09$ & $0.15 \pm 0.11$ & $0.33 \pm 0.23$ \\
Ratio of total tree biomass & $0.09 \pm 0.06$ & $0.04 \pm 0.04$ & $0.10 \pm 0.05$ & $0.23 \pm 0.10$ \\
\hline
\end{tabular}

Tab. 3 - Pairwise Pearson's correlation coefficients (below diagonal) and their significance ( $p$-values - above diagonal) among variables of young Scots pine trees. (DBH): diameter at breast height; (BGB): belowground biomass.

\begin{tabular}{|c|c|c|c|c|c|c|c|}
\hline Variable & 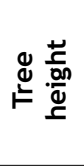 & 㔽 & 哭 & 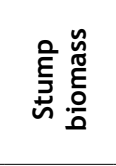 & 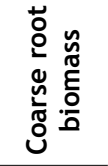 & 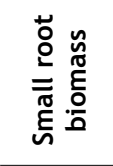 & $\begin{array}{l}\text { ज़ } \\
\frac{\oplus}{\tilde{n}} \\
\stackrel{0}{\circ}\end{array}$ \\
\hline Tree height & 1 & $<0.001$ & $<0.001$ & $<0.001$ & $<0.001$ & $<0.001$ & $<0.001$ \\
\hline Tree DBH & 0.86 & 1 & $<0.001$ & $<0.001$ & $<0.001$ & $<0.001$ & $<0.001$ \\
\hline Stand age & 0.93 & 0.69 & 1 & $<0.001$ & $<0.001$ & $<0.001$ & $<0.001$ \\
\hline Stump biomass & 0.79 & 0.91 & 0.73 & 1 & $<0.001$ & $<0.001$ & $<0.001$ \\
\hline Coarse root biomass & 0.80 & 0.91 & 0.68 & 0.96 & 1 & $<0.001$ & $<0.001$ \\
\hline Small root biomass & 0.66 & 0.89 & 0.61 & 0.93 & 0.90 & 1 & $<0.001$ \\
\hline Total belowground biomass & 0.80 & 0.92 & 0.74 & 0.99 & 0.99 & 0.93 & 1 \\
\hline
\end{tabular}

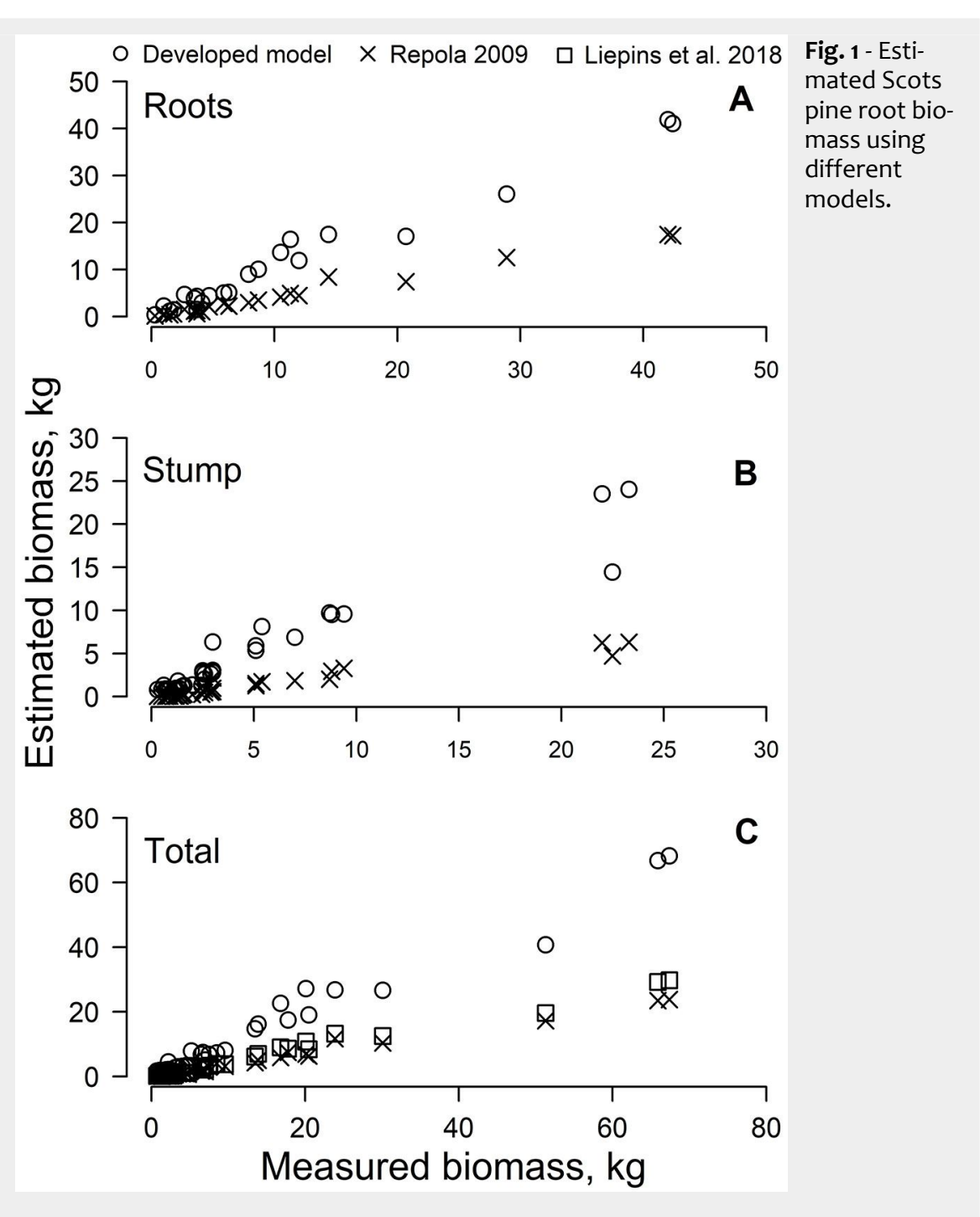


Tab. 4 - Parameter estimates and statistics of the models developed for root biomass prediction in young Scots pine trees in Latvia. (S): stem basal area; (V): stemwood volume. Standard error of parameter estimates $(a, b)$ are given in brackets. (BGB): Belowground biomass; (RMSE): root-mean square deviation; (df): degrees of freedom; $\left({ }^{*}\right): p<0.05 ;(* *): p<0.01 ;(* * *): p<0.001$.

\begin{tabular}{|c|c|c|c|c|c|}
\hline \multicolumn{2}{|c|}{ Model Statistics } & $\begin{array}{l}\text { Small roots } \\
(2-20 \mathrm{~mm})\end{array}$ & $\begin{array}{c}\text { Coarse roots } \\
(>20 \mathrm{~mm})\end{array}$ & Stump & Total BGB \\
\hline \multicolumn{2}{|l|}{ Model } & $\mathrm{S}=\mathrm{DBH}^{2}$ & $\mathrm{~V}=\mathrm{DBH}^{2} \cdot \mathrm{H}$ & $\mathrm{V}=\mathrm{DBH}^{2} \cdot \mathrm{H}$ & $\mathrm{V}=\mathrm{DBH}^{2} \cdot \mathrm{H}$ \\
\hline \multirow[t]{2}{*}{ Parameters } & $a$ & $\begin{array}{l}0.648^{* * *} \\
(0.156)\end{array}$ & $\begin{array}{l}-0.582 \\
(0.431)\end{array}$ & $\begin{array}{c}0.766^{*} \\
(0.291)\end{array}$ & $\begin{array}{l}1.543^{* *} \\
(0.496)\end{array}$ \\
\hline & $b$ & $\begin{array}{l}196.490^{* * *} \\
(13.317)\end{array}$ & $\begin{array}{l}57.872^{* * *} \\
(1.938)\end{array}$ & $\begin{array}{l}38.421^{* * *} \\
(1.746)\end{array}$ & $\begin{array}{c}110.155^{* * *} \\
(2.905)\end{array}$ \\
\hline \multicolumn{2}{|l|}{$\mathrm{R}^{2}$} & 0.858 & 0.977 & 0.929 & 0.975 \\
\hline \multicolumn{2}{|l|}{ Adj- $R^{2}$} & 0.854 & 0.976 & 0.927 & 0.974 \\
\hline \multicolumn{2}{|l|}{ df } & 1,36 & 1,21 & 1,37 & 1,37 \\
\hline \multicolumn{2}{|l|}{ F-statistics } & 217.7 & 891.7 & 484.0 & 1438.0 \\
\hline \multicolumn{2}{|c|}{ Overall significance $(p)$} & $<0.001$ & $<0.001$ & $<0.001$ & $<0.001$ \\
\hline \multicolumn{2}{|c|}{ RMSE } & 0.729 & 1.471 & 1.549 & 2.576 \\
\hline \multicolumn{2}{|c|}{ Relative error (\%) } & 36.9 & 42.6 & 28.4 & 25.9 \\
\hline
\end{tabular}

\section{Discussion}

In this study, the mean value of the total belowground biomass observed was similar to the estimates obtained for Scots pine in Central Europe (Xiao \& Ceulemans 2004), though comparable studies in the literature are still sparse and the belowground biomass estimates highly variable. Moreover, differences in biomass allocation pattern have been observed among populations of Scots pine, with a general trend of lower root biomass in Northern Europe stands (Oleksyn et al. 1999). Such differences have been explained by the effects of forest type, soil structure, moisture regime, and chemical composition (Dieter \& Elsasser 2002), which are considered key factors affecting the formation of root systems. This might also be related to age differences among the studied stands, as well as to the competition between young trees leading to their rapid development (Varik et al. 2013). The root system has proven to adapt to different environmental conditions, so trees growing in nutrientpoor forests (as is the case of our study area) are expected to develop a smaller amount of root biomass (Vanninen et al. 1996, Bhuiyan et al. 2017).

The distribution of belowground biomass components (Tab. 2) observed in this study was highly variable, according to previous reports (Fogel 1983, Pajtík et al. 2008, Petersson et al. 2012); however, the belowground biomass estimates (Tab. 2) were comparable to the results of Helmisaari et al. (2002) and Vanninen et al. (1996) in Finnish Scots pine, likely due to environmental conditions similar to those present in Latvia. Further, the ratio of belowground on total biomass of trees decreased with tree age, due to more rapid development of aboveground biomass over the same time span (Uri et al. 2012). Tree dimensions (in terms of $\mathrm{DBH}$ and $\mathrm{H}$ ) showed a strong correlation with belowground biomass components (Tab. 3); accordingly, both variables could be successfully used for root biomass estimation in nutrient-poor sites, as previously demonstrated by Xiao \& Ceulemans (2004) and Lehtonen et al. (2016). Stemwood volume (V) and stem basal area (S), which were included in our models (Tab. 4), have previously been demonstrated to be the best individual variables for fine root biomass estimation (Lehtonen et al. 2016). Since the best prediction of coarse root biomass was obtained using stemwood volume (Tab. 4), models for stump and total belowground biomass estimations were based on this variable. The high accuracy of $V$ in the prediction of root biomass has previously been shown for Scots pine seedlings (Geudens et al. 2004). The stem basal area was the best variable for small root biomass estimation (Tab. 4), indicating a link between the amount of absorbing roots and the crown size with the stem diameter, as proposed by the pipe-model theory (Shinozaki et al. 1964). Overall, biomass models using hence both $\mathrm{DBH}$ and $\mathrm{H}$ affect tree size over time (Liepins et al. 2018). The coarse root biomass estimates had the highest errors ( $R E=43 \%$ - Tab. 4), which could be explained by the smaller sample size comThe belowground biomass models developed in this study showed higher precision than previously published models for Scots pine, which were calibrated for a wider spectrum of stand ages (Repola 2009, Liepins et al. 2018). Herein, the application of stump and root models proposed by Repola (2009) led to underestimate the belowground biomass components (Fig. 1), suggesting a limitation for its wider application (Bronisz et al. 2016). The model developed by Liepins et al. (2018) closely followed the values we obtained using the Repola's model (Fig. 1C), indicating that $V$ as predictor had lower errors (Tab. 4), pared to the other analyzed components. stand age should be accounted for when estimating precise belowground biomass. Considering that similar belowground biomass estimates were obtained in Estonia (Varik et al. 2013), along with the similarity of Scots pine forest structure therein, we speculate that our models might be successfully applied to predict belowground biomass of young Scots pine trees over the eastern Baltic region. However, a more comprehensive dataset covering a larger area of comparable conditions (Addo-Danso et al. 2016) would be desirable to this purpose.

\section{Conclusions}

The models developed in this study reduced the overestimation of belowground biomass of young Scots pine trees, as compared with previously developed models based on a full rotation cycle in the Baltic Sea region. This leads to a reduction of uncertainty in the estimation of carbon budget of belowground biomass. The developed models also appear to be useful tools for the estimation of belowground biomass supply in young Scots pine stands in relation to the potential for bioenergy production. However, the analysis of a more comprehensive dataset is desirable, in order to account for the effect of the social status of trees, and for the withinand between-stand variation.

\section{Acknowledgements}

This study was funded by the European Regional Development Fund Project "Development of decision support tools for prognosis of storm damage in forest stands on peat soils" (No. 1.1.1.1/16/A/260).

\section{References}

Aalde H, Gonzalez P, Gytarsky M, Krug T, Kurz WA, Ogle S, Raison J, Schoene D, Ravindranath NH (2006). Forest Land. In: "2006 IPCC Guidelines for National Greenhouse Gas Inventories, Prepared by the National Greenhouse Gas Inventories Programme" (Eggleston HS, Buendia L, Miwa K, Ngara T, Tanabe K eds). IGES, Hayama, Japan, pp. 4.1-4.83.

Addo-Danso SD, Prescott CE, Smith AR (2016). Methods for estimating root biomass and production in forest and woodland ecosystem carbon studies: a review. Forest Ecology and Management 359: 332-351. - doi: 10.1016/j.foreco.20 15.08.015

Ahti T, Hämet-Ahti L, Jalas J (1968). Vegetation zones and their sections in northwestern Europe. Annales Botanici Fennici 5 (5): 169-211. [online] URL: http://www.jstor.org/stable/23724233 Baumanis I, Jansons A, Neimane U (2014). Priede. Selekcija, genetika un seklkopiba Latvija [Scots pine. Selection, genetics and breeding in Latvia]. Latgales druka, Rezekne, Latvia, pp. 325. [in Latvian]

Bardulis A, Jansons A, Liepa I (2012). Belowground biomass production in young stands of Scots pine (Pinus sylvestris L.) on abandoned agricultural land. In: Proceedings of the $18^{\text {th }} \mathrm{An}$ nual International Scientific Conference "Research for Rural Development” (Treija S, Skuja I 
eds). Jelgava (Latvia) 16-18 May 2012. LLU, Jelgava, Latvia, pp. 49-54.

Bhuiyan R, Minkkinen K, Helmisaari HS, Ojanen P, Penttilä T, Laiho R (2017). Estimating fineroot production by tree species and understory functional groups in two contrasting peatland forests. Plant and Soil 412: 299-316. - doi: 10.100 7/s11104-016-3070-3

Brassard BW, Chen HY, Bergeron Y, Paré D (2011). Coarse root biomass allometric equations for Abies balsamea, Picea mariana, Pinus banksiana, and Populus tremuloides in the boreal forest of Ontario, Canada. Biomass and Bioenergy 135 (10): 4189-4196. - doi: 10.1016/j. biombioe.2011.06.045

Bronisz K, Strub M, Cieszewski C, Bijak S, Bronisz A, Tomusiak R, Wojtan R, Zasada M (2016). Empirical equations for estimation aboveground biomass of Betula pendula growing on former farming in central Poland. Silva Fennica 50 (4): id 1559. - doi: 10.14214/sf.1559

Brunner I, Godbold DL (2007). Tree roots in a changing world. Journal of Forest Research 12 (2): 78-82. - doi: 10.1007/s10310-006-0261-4

Bušs K (1976). Latvijas PSR meža tipologijas pamati [Basis of forest classification in SSR of Latvia]. LRZTIPI, Riga, Latvia, pp. 24. [in Latvian]

Chakraborty T, Saha S, Reif A (2016). Biomass equations for European beech growing on dry sites. iForest 9: 751-757. - doi: 10.3832/ifor1881009

Cairns MA, Brown S, Helmer EH, Baumgardner GA (1997). Root biomass allocation in the world's upland forests. Oecologia 111: 1-11. - doi: 10.1007/s004420050201

Dieter M, Elsasser P (2002). Carbon stocks and carbon stock changes in the tree biomass of Germany forests. Forstwissenschaftliches Centralblatt 121 (4): 195-210. - doi: 10.1046/j.14390337.2002.02030.x

IUCN (1993). Environmental status reports 1993: Estonia, Latvia, Lithuania. Michigan University, USA, pp. 201.

Finér L, Ohashi M, Niguchi K, Hirano $Y$ (2011). Factors causing variation in fine root biomass in forest ecosystems. Forest Ecology and Management 261: 265-277. - doi: 10.1016/j.foreco.20 10.10.016

Finér L, Helmisaari HS, Lõhmus K, Majdi H, Brunner I, Brja I, Eldhuset T, Godbold D, Grebenc T, Konôpka B, Kraigher H, Möttönen MR, Ohashi M, Oleksyn J, Ostonen I, Uri V, Vanguelova E (2007). Variation in fine root biomass of three European tree species: beech (Fagus sylvatica L.), Norway spruce (Picea abies L. Karst.), and Scots pine (Pinus sylvestris L.). Plant Biosystems 141 (3): 394-405. - doi: 10.1080/112635007016258 97

Fogel R (1983). Root turnover and productivity of coniferous forest. Plant and Soil 71: 75-85. doi: 10.1007/BF02182643

Geudens G, Staelens J, Kint V, Goris R, Lust N (2004). Allometric biomass equations for Scots pine (Pinus sylvestris L.) seedlings during the first years of establishment in dense natural regeneration. Annals of Forest Science 61: 653659. - doi: 10.1051/forest:2004067

Helmisaari HS, Makkonen K, Kellomäki S, Valtonen E, Mälkönen E (2002). Below- and aboveground biomass, production and nitrogen use in Scots pine stands in Eastern Finland. Forest Ecology and Management 165: 317-326. - doi: 10.1016/S0378-1127(01)00648-X

Hytteborn H, Maslov AA, Nazimova DI, Rysin LP (2005). Boreal forests of Eurasia. In: "Coniferous forests, ecosystems of the world" (Andersson $\mathrm{F}$ ed). Elsevier, Amsterdam, Netherlands, pp. 23-99. [online] URL: http://books.google. com/books?id=_YoOoxKYSJAC

LEGMC (2016). Climate of Latvia. Web site. [online] URL: http://meteo.lv/lapas/laika-apstakli/kli matiska-informacija/latvijas-klimats/latvijas-klim ats? $i d=1199 \&$ nid $=562$

Lehtonen A, Palviainen M, Ojanen P, Kalliokoski T, Nöjd P, Kukkola $M$, Penttilä T, Mäkipää R, Leppälammi-Kujansuu J, Helmisaari HS (2016). Modelling fine root biomass of boreal tree stands using site and stand variables. Forest Ecology and Management 359: 361-369. - doi: 10.1016/j.foreco.2015.06.023

Levers C, Verkerk PJ, Müller D, Verburg PH, Butsic V, Leitão Lindner $M$, Kuemmerle T (2014). Drivers of forest harvesting intensity patterns in Europe. Forest Ecology and Management 315: 160-172. - doi: 10.1016/j.foreco.2013.12.030

Liepins J, Lazdins A, Liepins K (2018). Equations for estimating above- and belowground biomass of Norway spruce, Scots pine, birch spp. and European aspen in Latvia. Scandinavian Journal of Forest Research 33: 58-70. - doi: 10.10 80/02827581.2017.1337923

Litton CM, Ryan MG, Tinker DB, Knight DH (2003). Belowground and aboveground biomass in young postfire logepole pine forests of contrasting tree density. Canadian Journal of Forest Research 33 (2): 351-363. - doi: 10.1139/x 02-181

López-Serrano PM, López-Sánchez CA, Díaz-Varela RA, Corral-Rivas JJ, Solís-Moreno R, VargasLarreta B, Gonzalez JG (2015). Estimating biomass of mixed and uneven-aged forests using spectral data and a hybrid model combining regression trees and linear models. iForest 9: 226-234. - doi: 10.3832/ifor1504-008

Makkonen K, Helmisaari HS (1998). Seasonal and yearly variations of fine-root biomass and necromass in a Scots pine (Pinus sylvestris L.) stand. Forest Ecology and Management 102: 283-290. - doi: 10.1016/S0378-1127(97)00169-2

Makkonen K, Helmisaari HS (2001). Fine-root biomass and production in Scots pine stands in relation to stand age. Tree Physiology 21: 193198. - doi: 10.1093/treephys/21.2-3.193

Muukkonen P, Mäkipää R (2006). Biomass equations for European trees: addendum. Silva Fennica 40 (4): 763-773. [online] URL: http:// jukuri.luke.fi/bitstream/handle/10024/532621/bi omass.pdf

Neumann M, Moreno A, Mues V, Härkönen S, Mura M, Bouriaud O, Lang M, Achten WMJ, Thivolle-Cazat A, Bronisz K, Merganič J, Decuyper M, Alberdi I, Astrup R, Mohren F, Hasenauer $H$ (2016). Comparison of carbon estimation methods in European forests. Forest Ecology and Management 361: 397-420. - doi: 10.1016/j.foreco.2015.11.016

Ohashi $M$, Kilpeläinen J, Finér $L$, Risch $A C$, Domisch T, Neuvonen S, Niemelä P (2007). The effect of red wood ant (Formica rufa group) mounds on root biomass, density, and nutrient concentrations in boreal managed forests.
Journal of Forest Research 12 (2): 113-119. - doi: 10.1007/s10310-006-0258-z

Oleksyn J, Reich PB, Chalupka W, Tjoelker MG (1999). Differential above- and below-ground biomass accumulation of European Pinus sylvestris 127 populations in a 12-year-old provenance experiment. Scandinavian Journal of Forest Research 14: 7-17. - doi: 10.1080/0282758990 8540804

Pajtík J, Konôpka B, Lukac M (2008). Biomass functions and expansion factors in young Norway spruce (Picea abies [L.] Karst) trees. Forest Ecology and Management 256: 1096-1103. - doi: 10.1016/j.foreco.2008.06.013

Petersson H, Holm S, Ståhl G, Alger D, Fridman J, Lehtonen A, Lundström A, Mäkipää R (2012). Individual tree biomass equations or biomass expansion factors for assessment of carbon stock changes in living biomass - A comparative study. Forest Ecology and Management 270: 78-84. - doi: 10.1016/j.foreco.2012.01.004

R Core Team (2016). R: a language and environment for statistical computing. R Foundation for Statistical Computing, Vienna, Austria. Web site. [online] URL: http://www.r-project.org

Repola J (2009). Biomass equations for Scots pine and Norway spruce in Finland. Silva Fennica 43 (4): 625-647. - doi: 10.14214/sf.184 Sanford RLJ, Cuevas E (1996). Root growth and rhizosphere interactions in tropical forests. In: "Tropical Forest Plant Ecophysiology" (Mulkey SS, Chazdon RL, Smith AP eds). Chapman and Hall, New York, USA, pp. 268-300. - doi: 10.1007/ 978-1-4613-1163-8_10

Seidl R, Schelhaas MJ, Rammer W, Johannes V (2014). Increasing forest disturbances in Europe and their impact on carbon storage. Nature Climate Change 4: 806-810. - doi: 10.1038/nclimate 2318

Shinozaki K, Yoda K, Hozumi K, Kira T (1964). A quantitative analysis of plant form - The pipe model theory. I. Basic analyses. Japanese Journal of Ecology 14: 97-104.

Sochacki SJ, Ritson P, Brand B, Harper RJ, Dell B (2017). Accuracy of tree biomass sampling methodologies for carbon mitigation projects. Ecological Engineering 98: 264-274. - doi: 10.101 6/j.ecoleng.2016.11.004

Thomas SC, Martin AR (2012). Carbon content of tree tissues: a synthesis. Forests 3: 332-352. doi: 10.3390/f3020332

Uri V, Varik M, Aossar J, Kanal A, Kukumägi M, Lõhmus K (2012). Biomass production and carbon sequestration in a fertile silver birch (Betula pendula Roth) forest chronosequence. Forest Ecology and Management 267: 117-126. doi: 10.1016/j.foreco.2011.11.033

Uri V, Tullus H, Lõhmus K (2002). Biomass production and nutrient accumulation in shortrotation grey alder (Alnus incana (L.) Moench) plantation on abandoned agricultural land. Forest Ecology and Management 161: 161-179. - doi: 10.1016/S0378-1127(01)00478-9

Vanninen $P$, Ylitalo $H$, Sievänen $R$, Mäkelä A (1996). Effects of age and site quality on the distribution of biomass in Scots pine (Pinus sylvestris L.). Trees 10 (4): 231-238. - doi: 10.1007/BF 02185674

Varik M, Aosaar J, Ostonen I, Lõhmus K, Uri V (2013). Carbon and nitrogen accumulation in belowground tree biomass in a chronose- 
quence of silver birch stands. Forest Ecology and Management 302: 62-70. - doi: 10.1016/j.for eco.2013.03.033

Xiao CW, Ceulemans R (2004). Algometric relationships for below- and aboveground biomass of young Scots pines. Forest Ecology and Management 203: 177-186. - doi: 10.1016/j.foreco. 2004.07.062

Zianis D, Muukkonen P, Mäkipää R, Mencuccini $M$ (2005). Biomass and stem volume equations for tree species in Europe. Silva Fennica Monographs 4, The Finish Forest Research Institute, Tampere, Finland, pp. 63. [online] URL: http:// jukuri.luke.fi/bitstream/handle/10024/512732/951 -40-1984-9.pdf 